УДК: 614:32](477)

\author{
JEL Classification: A11, I18, E29, O15, H51. \\ DOI 10.35433/ISSN2410-3748-2020-2(27)-6
}

Корнійчук Олександр, к. е. н., старший науковий співробітник відділу демографічного моделювання і прогнозування Інституту демографії та соціальних досліджень ім. М.В. Птухи НАН України https://orcid.org/0000-0001-7357-0598

\title{
ТЕОРЕТИЧНІ ПЕРЕДУМОВИ ФОРМУВАННЯ ПОЛІТИКИ ДЕРЖАВИ У СФЕРІ ОХОРОНИ ЗДОРОВ'Я УКРАЇНИ
}

В компаративному контексті розглянуто характерні особливості економічної теорії розвитку і доиільність ї̈ застосування у сфері охорони здоров'я. Обтрунтована необхідність впровадження ідей та положень «традииї розвитку»

(девелопменталістської традиції), які пройшли успішне застосування у низиі розвинених країн у період знаходження їх на етапі перехідних економік. Поняття сфера охорони здоров'я визначен як сукупність видів надання медичної допомоги та галузей в яких виготовляються споживчі вартості для задоволення потреб населення у вигляді корисного ефекту - збереження, підтримання здоров'я та лікування хвороб населення. Вона є складовою сфери послуг, як галузі начіонального господарства де створюються продукти трудової діяльності у формі послуг - як споживчої вартості з корисним ефектом для задоволення потреб особистості і населення. Визначається необхідність у її випереджальному розвитку.

Змістом державного протекиіонізму і втручань у сферу охорони здоров'я має бути розвиток потужностей медичних закладів.

Ключовою ланкою в системі охорони здоров'я Украӥни має стати ПМД на засадах сімейної медицини. Вона спроможна наростити попит на медичні послуги та розширити відносини між закладами які надають медичну допомогу. Зазначене вирогідно призведе до зменшення витрат на спеціалізовану та екстрену медичні допомоги.

Для цьього необхідно будівництва нової інфраструктури - доріг, засобів зв'язку, інтернет-мережі, спортивних комплексів, виробництво профілактичних засобів від інфекиійних захворювань, створення інформаційних продуктів про здоровий спосіб життя, медичного транспорту, розгортання телемедицини. Це має базуватись на опращюванні сімейними лікарями оптимальних маршрутів руху пацієнтів до лікарів спеціалізованої ланки, які спроможні надавати якісні медичні послуги.

Ключові слова: теоретичні передумови, «традииія розвитку», державна політика, сфера охорони здоров'я. 


\section{THEORETICAL ASPECTS OF THE SUBSTANTIATION OF THE POLICY IN THE SPHERE OF PUBLIC HEALTH OF UKRAINE}

In a comparative context, the characteristic features of economic theory of development and the feasibility of its application in the field of health care are considered. The need to implement the ideas and provisions of the "tradition of development" (developmentalist tradition), which have been successfully applied in a number of developed countries during their period in transition economies, is substantiated. The concept of health care is defined as a set of types of medical care and industries in which consumer values are produced to meet the needs of the population in the form of a beneficial effect - the preservation, maintenance of health and treatment of diseases of the population. It is a component of the service sector, as a sector of the national economy where the products of labor are created in the form of services - as consumer value with a useful effect to meet the needs of the individual and the population. The need for its advanced development is determined.

The content of state protectionism and interventions in the field of health care should be the development of medical facilities.

PMD on the basis of family medicine should become a key link in the health care system of Ukraine. It is able to increase the demand for medical services and expand relations between institutions that provide medical care. This will advantageously reduce the cost of specialized and emergency medical care.

This requires the construction of new infrastructure - roads, communications, Internet, sports facilities, production of preventive measures against infectious diseases, the creation of information products about a healthy lifestyle, medical transport, the deployment of telemedicine. This should be based on the development by family physicians of optimal routes for patients to move to specialized physicians who are able to provide quality medical services.

Key words: sphere of health protection, politics, theoretical aspects, tradition of development

Постановка проблеми. Розрив між Україною та країнами Центральної і Східної Свропи за здатністю систем охорони здоров’я надавати якісну і доступну медичну допомогу протягом останніх двох десятиліть лише зростав. Незважаючи на збільшення в останні десять років фінансування [1] ситуація у сфері охорони здоров'я не змінилася і відтак потребує системного покращення. Як свідчать дані Держстату України [2] близько третини населення взагалі не звертаються за отриманням медичної допомоги, як правило, у зв'язку з фінансовою неспроможністю оплатити послуги. Смертність серед сільських мешканців більш ніж у 2 рази перевищує цей показник у містах [3]. Офіційна заробітна плата значної частини медичного персоналу $є$ нижчою ніж в промисловості і ніяким чином не пов'язана 3 кінцевими результатами лікування пацієнтів. Впровадження демократичних підходів до управління та розвитку системи 
охорони здоров’я на базі сучасної профілактичної та первинної медичної допомоги на засадах сімейної медицини до 2014 р. не було зафіксовано. Наслідком цієї ситуації стала деградація у сфері охорони здоров’я та перше місце України серед європейських держав за кількістю передчасних смертей громадян у працездатному віці. За авторською оцінкою сучасне управління системою охорони здоров'я потребує застосування підходів, що спираються на досвід «традиції розвитку». Остання сприяла свого часу прийняттю управлінських рішень по виведенню економік у тому числі у сфері охорони здоров'я - Англії, США, Німеччини та інших держав, на належний рівень розвитку. Зазначені підходи зберегли свою актуальність для нинішніх умов розвитку України особливо стосовно сфери охорони здоров'я.

Аналіз основних досліджень і публікацій. Розробці теоретичних положень та ідейної бази «традицій розвитку» приділялась увага такими науковцями як Дж. Батеро та А. Сево [5], А. Гамільтоном [6], С.Кузнецем [7], Г.Мюрдалем [8], Ф.Лістом [9], А.Хіршманом [10] та А. Люїсом [11] та іншими. Разом 3 тим дослідженню можливостей iï використання в інтересах сфера охорони здоров’я приділялось недостатньо уваги.

Метою статті є обгрунтування актуальності застосування положень «традиції розвитку» у сучасну політику щодо системи охорони здоров’я України з метою приведення останньої до належного рівня ефективності щодо потреб суспільства. Одне із завдань полягало при цьому у проведенні огляду сучасних економічних теорій для їх оптимального застосування при розробці державної політики у сфері охорони здоров’я України.

Виклад основного матеріалу. Найбільш узагальнено під категорією «традиція розвитку» слід розуміти сукупність накопиченого досвіду розробки теорії розвитку і прийняття прагматичних рішень на їі основі, які стосовно низки країн створювали підгрунтя для їх переходу від відсталих до економічно ефективних. 
Для розкриття економічного дискурсу функціонування системи охорони здоров'я важливим $\epsilon$ визначення іiі сутності як складової національної економіки по наданню соціальних послуг. Так, за авторською оцінкою, сфера охорони здоров'я $є$ сукупністю видів надання медичної допомоги (профілактичної, первинної, невідкладної, вторинної, екстреної, третинної, паліативної та хоспісної, реабілітаційної) та галузей (фармацевтична, виробництво обладнання та інструментів та ін.) в яких виготовляються споживчі вартості для задоволення потреб населення у вигляді корисного ефекту - збереження, підтримання здоров'я та лікування хвороб населення. Вона $є$ складовою сфери послуг, як галузі національного господарства де створюються продукти трудової діяльності у формі послуг - як споживчої вартості 3 корисним ефектом для задоволення потреби особистості і населення. Це сфера нематеріального виробництва для якої характерно: єдність процесу виробництва i споживання; неможливість нагромадження та транспортування. Функціональною призначеністю є відтворення можливостей з точки зору здоров'я людей [12, с.544].

Сфера охорони здоров'я потребує випереджального розвитку перед матеріальною сферою. Зазначеним обгрунтовується іiі пріоритетність у суспільному виробництві задля блага людини. За експертними оцінками у кінці XX ст. обсяги капіталовкладень у сферу охорони здоров’я склали 9\%, а продуктивність праці зросла більш ніж на 1\% [12].

Аналіз в історичний ретроспективі успішних політик свідчить, що 3 XVI ст. і по сьогодення в економіці передових країн використовуються положення «традиції розвитку» (девелопменталіська традиція). Ї̈ї інтелектуальний родовід бере початок від політиків, яких цікавило розв'язання реальних проблем, а не чиста теорія [4, с.115]. Їх теоретичне обгрунтування у XVI- XVII ст. досліджено італійськими економістами Джованні Батеро та Антоніо Сево [4, с.117]. 
Меркантилісти, як прихильники девелопменталіської традиції у XVII-XVIII ст. обгрунтували політичне втручання для розвитку високопродуктивних галузей національної економіки, вважаючи ознакою економічного успіху активне сальдо торгівельного балансу.

В кінці XVIII ст. i в XIX ст. девелопменталіська традиція концентрувалась на виробництві. Теорію А.Гамілтона стосовно сприяння незміцнілій економіці розвинув німецький економіст Фредерік Ліст. Її сутність полягає в тому, що вільна торгівля відсталих країн з розвиненими шкодить першим. До відсталих країн в той період були віднесені США і Німеччина, а розвинених - Велика Британія. Зазначені підходи були впроваджені в Німеччині та США до середини ХХ ст. В сучасному світі девелопменталіська традиція розвивалась в працях С.Кузнеця, Г.Мюрдала, А.Хіршмана, А.Люїса та ін.

Вона стала підгрунтям успішних економік у Великобританії у XVIII ст., США і Німеччині у XIX ст. та Китаї у XX-XXI ст. Для країн 3 перехідною економікою в ній обгрунтовуються шляхи, як наздогнати розвинені країни на основі створення високотехнологічних виробничих потужностей та розробки новітніх технологій, включаючи сферу охорони здоров’я. Це має грунтуватись на урядовому втручанні в соціальноекономічні процеси галузі. Що стосується сфери охорони здоров’я України, то якщо уряд належним чином не втручається шляхом регулювання сприянню впровадження нових технологій у сфері охорони здоров'я - електронна медицина, підготовка та використання сучасних сімейних лікарів, то існуюча інфраструктура системи охорони здоров’я безупинно втягуватиме, насамперед первинну ланку до старої системи «Семашко», яка надає низькопродуктивні послуги iз використанням дешевої робочої сили.

Порівняння різних економічних теорій дозволяє повніше оцінити спроможність кожної із них принести найбільший зиск у сфері охорони 
здоров’я. При цьому в якості критеріїв використовується трактування тією чи іншою теорією таких інституцій як господарство та його найголовнішої частини - людину, світ, причини зміни ладу та відповідних політичних рекомендацій. Для України у цьому контексті актуальною є фахова оцінка соціально-економічної політики у сфері охорони здоров’я на підставі тієї чи іншої економічної теорії або тих чи інших обгрунтувань [4, с.140].

Особливістю дискусій в державі щодо соціально-економічної політики в сфері охорони здоров'я є протиставлення позиції влади, яка в тих чи інших підходах практично позбавлена вибору та популістичних силах, які свідомо поляризують дискусію показуючи в негативному світлі будь-які спроби змін. Причиною цього $є$ використання теми перспективного розвитку охорони здоров'я не в науково-обгрунтованій площині, а в ракурсі політичних технологій, які базуються на здобутті влади будь-якою ціною.

Насправді у економічних теоріях, які тим чи іншим чином кладуться в основу прийняття рішень, є достатньо позицій, які співпадають. Мистецтво управління державою полягає у виборі найкращого інструменту із запропонованих економічними теоріями для обгрунтування стратегічних рішень. На наш погляд у сфері охорони здоров'я цим очікуванням відповідає «традиція розвитку». Так як і класична та кейнсіанська економічні теорії вона вважає, що господарство складаються 3 класів. Поруч 3 класичною, шумпетеріанською, певною мірою кейнсіанською, інституціональною, поведінковою [4,с.140-144], «традиція розвитку» схиляється до виробництва як найголовнішої частини господарства (на відміну від неокласичної, яка відносить до цього обмін і споживання та австрійської - обмін). За оцінками девелопменталіської традиції економічний лад змінюється через розвиток потужностей виробництва. Це, на відміну від класичної, яка вважає, що через накопичення капіталу (інвестування) неокласична, австрійська - 
особистого вибору, шумпетеріанська (технологічних інновацій) та інституціональної (взаємодія людей та інституцій).

Сутність політичних рекомендацій «традиції розвитку» полягає у застосуванні тимчасового державного протекціонізму i втручання. Класична i неокласична теорії та австрійська школа звертаються до вільного ринку. Державне втручання припускають неокласична та поведінкова економічні теорії [4, с.144].

Виходячи із канонів девелопменталіської школи сутністю державного протекціонізму і втручань у сферу охорони здоров’я має бути створення належного концентрованого процесу надання медичних послуг на основі розвитку потужностей медичних закладів. Це має передбачати проведення адміністративно-територіальної реформи та реформи органів місцевого самоврядування в інтересах створення великих об'єднаних територіальних громад міст, сіл та селищ для розгортання укрупнених амбулаторій сімейної медицини, центрів первинної медичної допомоги (ПМД). Це ж стосується і створення великих госпітальних округів 3 високим рівнем навантаження на медичний персонал та сучасне медичне обладнання. Аналогічний підхід має стосуватись і обласного рівня по розгортанню сучасних високотехнологічних університетських клінік для надання високоспеціалізованої допомоги. При цьому важливою роллю держави в особі Президента України, парламенту, уряду та органів місцевого самоврядування є створення і розвиток нової інфраструктури системи охорони здоров’я та фармацевтичної галузі.

Висока динаміка розвитку економіки може бути досягнена на основі державного сприяння розвитку пріоритетних галузей, які мають надзвичайно тісні зв’язки з іншими на основі відносин купівлі-продажу (сталеварна, автомобільна) та ін. галузі. Автором цієї ідеї є Хіршман.

Що стосується системи охорони здоров'я, то ключовою ланкою в Україні має стати ПМД на засадах сімейної медицини, яка за авторським 
припущенням, спроможна наростити попит на медичні послуги та розширити відносини між закладами які надають профілактичну, спеціалізовану та високоспеціалізовану медичні допомоги. Це має сприяти розширенню відносин купівлі-продажу у сфері охорони здоров’я. В наступному це, вірогідно, призведе до помітного зменшення витрат на спеціалізовану та екстрену медичні допомоги.

Це в свою чергу вимагає будівництва нової інфраструктури - доріг, засобів зв'язку, інтернет-мережі, спортивних комплексів, виробництво профілактичних засобів від інфекційних захворювань, створення нових інформаційних продуктів про здоровий спосіб життя, медичного транспорту, створення електронної та телемедицини. Наслідком цього має стати зменшення смертності на основі зниження частоти лікарських помилок. Це має базуватись на опрацюванні сімейними лікарями оптимальних маршрутів руху пацієнтів до лікарів спеціалізованої ланки, які спроможні надавати якісні медичні послуги.

В умовах російсько-української війни і падінням ВВП на 20\% стратегічно правильним кроком уряду України є підтримання належного попиту в господарстві шляхом витрачання коштів, більше ніж вони зароблені. Це ж стосується і сфери охорони здоров’я щодо фінансування витрат на створення нової системи ПМД на засадах сімейної медицини, насамперед в сільській місцевості. Зазначене має запустити механізми розширеного попиту на інші види медичних послуг. Розширенню попиту має сприяти також збільшення мінімальних зарплат та пенсій.

Досвід США по подоланню найглибшої кризи вказує на потребу достатньо енергійних і швидких реформаторських дій уряду в рамках «першого Нового курсу» 1933-1934 рр. та посилення регулювання фінансової системи (банків, фінансових установ та будівельної інфраструктури). Ще більш глибокі зміни у 1935-1938 рр. стосувались соціального захисту пенсіонерів, страхування та зміцнення профспілок [4, 
c.71]. Достатньо глибинні реформи, які актуальні нині для України, були проведені у 30 pp. XX ст. у Швеції на основі розбудови держави соціального добробуту. Зазначене було досягнуто на основі впровадження податку на доходи, введення страхування на випадок безробіття, збільшення пенсій, гарантування мінімальних цін та кредитування фермерських господарств, налагодження співпраці профспілок i роботодавців по припиненню ворожнечі.

В сучасних умовах Україна потребує активної ролі держави у кожній галузі з метою створення соціального добробуту є розширенням трудових прав та 3 метою підвищення мобільності населення, впровадження інновацій та збільшення інвестицій. Актуальним є створення державних підприємств у високотехнологічних галузях. До прикладу у системі охорони здоров'я відносяться нано- і біотехнології, від розробок яких ухиляються приватні інституції у зв'язку з високою ризикованістю.

Реальним кроком у соціальному захисті громадян України у сфері охорони здоров’я стало створення Національної служби здоров'я України, фінансування якої має зростати синхронно із зростанням національного доходу. Для України актуальним $є$ запровадження антициклічної промислової політики на основі нарощування державних видатків на систему охорони здоров'я та координацію політики у виробництві фармацевтичних засобів та фінансування медико-біологічних наук на основі індикативного п'ятирічного планування. Для цього слід враховувати успішний досвід Франції, Південної Кореї, Японії та інших держав.

Україна потребує імпортозамінної індустріалізації. Досвід розвинених країн вказує, що в ринкових умовах потенціал найкраще розкривається в умовах оптимального регулювання та заохочення з боку держави. 
Реальною загрозою для динамічного економічного зростання на основі індустріалізації і забезпечення на цій основі підвищеного попиту на послуги системи охорони здоров'я є МВФ та Світовий банк 3 класичною від 70 рр. ХХ ст. програмою структурних реформ. [4, с.83].

За 48 років кожна програма, що іiі застосовували вищезазначені інституції призводила до значного зменшення темпів зростання економіки та унеможливила промислову революцію в третіх країнах. Ці «структурні реформи», які нині нав’язуються Україні передбачають зменшення ролі уряду в економічному житті, в послабленні законодавчого захисту власного ринку та приватизації держпідприємств. В цей час успіх мали Японія на Південна Корея, які запроваджували суттєве державне втручання. Для системи охорони здоров'я це означає потребу у суттєвому посиленні регулювання охорони здоров’я, розвитку державних підприємств та протекціонізму у захисті власних надавачів послуг та виробників фармацевтичної продукції. Просування іноземних виробників та надавачів послуг в системі охорони здоров’я $є$ підтвердженням «структурних реформ» МВФ на шкоду України.

Досвід запровадження ринкових відносин в країнах Центральної та Східної Свропи був більш вдалим ніж на пострадянському просторі на основі поступального включення реформ та кращого рівня фахівців. Глобалізаційний тиск із середини 90 pp. XX ст. на економіку України пов'язаний 3 диктатом відкриття вільної торгівлі та лібералізацію внутрішнього господарства [4, с.87].

Завдання країни полягає у використанні інформаційних (інтернет) та фінансових мереж у власній вигоді із залученням інвесторів до сфери охорони здоров’я та ін. та протекціоністських дій по захисту власного ринку. Ключовим уроком фінансової кризи з 2007 р. є подолання надмірної лібералізації фінансового ринку. Для системи охорони здоров’я це означає чітке фінансове регулювання через Національну службу здоров’я України. 
Зазначене має суттєво розширити державне втручання в інтересах розвитку ПМД на засадах сімейної медицини.

В процесі нарощування фонду озброєності охорони здоров'я України достатньо вірогідним в перспективі може бути зменшення продуктивності праці у зв’язку з високою вартістю оплати праці, збільшенням кількості працюючих у процесі впровадження нових технологій; розширенням асортименту послуг та збільшенням кількості обслуговуючого персоналу. $[12$, c.545].

Висновки. У дослідженні розкрита сутність успішних практик у політиці охорони здоров’я - «традицій розвитку» та обгрунтовано напрями впровадження державної політики при реформуванні системи медичної допомоги в Україні. Запропоновано підходи до іiі удосконалення на основі застосування «традицій розвитку», які успішно зарекомендували себе в сучасних передових країнах.

Зазначене має базуватись на посиленні протекціонізму та державного втручання в реформування сфери охорони здоров'я через Національну службу здоров’я України (НСЗУ), Міністерство охорони здоров’я України стосовно створення сучасних видів надання медичної допомоги. Роль держави має полягати у вдосконаленні критеріїв та механізмів фінансування сфери охорони здоров’я через НСзУ, розробці стратегії та фінансуванні проектів. В ході проведення адміністративнотериторіальної реформи та реформи органів місцевого самоврядування необхідне створення нових госпітальних округів і університетських клінік. В умовах концентрації надання послуг та конкуренції достатньо вірогідним буде нарощування монополізації у спеціалізованій та високоспеціалізованій допомозі, інтеграція фармвиробників із закладами охорони здоров’я та із системою громадського харчування.

До перспектив подальших досліджень зазначених проблем слід віднести узагальнення досвіду застосування у сфері охорони здоров’я 
«традиції розвитку» країни-аналога. За територією, населенням та державним устроєм і формою державного правління такою країною може стати Франція.

\section{СПИСОК ВИКОРИСТАНИХ ДЖЕРЕЛ}

1. Статистичний бюлетень «Національні рахунки охорони здоров’я (HРО3) України. [Електронний ресурс] // Державна служба статистики України. - 2017. - Режим доступу до ресурсу: http://www.ukrstat.gov.ua/druk/publicat/Arhiv_u/15/Arch_nroz_bl.htm

2. Держстат України. [Електронний ресурс] - Режим доступу: Www.ukrstat.gov.ua/

3. Інститут демографії та соціальних досліджень імені М.В. Птухи Національно академії наук України [Електронний ресурс] - Режим доступу: https://idss.org.ua/index

4. Чанг Х.-Ю. Економіка. Інструкція з використання / Х. Ю. Чанг. Київ: Наш Формат, 2016. - 400 с.

5. Botero G. The Reason of State / G. Botero. - Chicago: Loyola University, 2017. -270 p.

6. Hamilton A. The Works of Alexander Hamilton: [Miscellanies, 17891795: France; Duties On Imports; National Bank; Manufactures; Revenue Circulars; Reports On Claims, Etc / A. Hamilton., 2010. - 604 p.

7. Kuznets S. Population Capital \& Growth: Selected Essays / S. Kuznets., 1980. $-356 \mathrm{p}$.

8. Myrdal G. Gunnar Myrdal on Population Policy in the Underdeveloped World / G. Myrdal // Population and Development Review / G. Myrdal., 1987. (3; № 13). - pp. 531-540.

9. List F. The National System of Political Economy / F. List. - London: Longmans, Green and Co., 1909. - 121 p. 
10. Hirschman A. Crossing Boundaries: Selected Writings / A. Hirschman. New-York: Zone Books; First Edition edition, 1999. - 112 p.

11. Льюис У. А. Машина экономического роста замедляет ход / У. А. Льюис // Мировая экономическая мысль. Сквозь призму веков : в 5 т. / Моск. гос. ун-т им. М. В. Ломоносова ; [сопред. редкол. : Г. Г. Фетисов, А. Г. Худокормов]. Т. V, кн. 1. Всемирное признание. Лекции нобелевских лауреатов / [отв. ред. Г. Г. Фетисов]. - М. : Мысль, 2004. - С. 373-385.

12. Економічна енциклопедія: у трьох томах. Т.3 / Редкол.: С.В. Мочерний (відп.ред.) та ін. К.: Видавничий центр «Академія», 2002 $952 \mathrm{c}$.

\section{REFERENCES}

1. Statystychnyi biuleten «Natsionalni rakhunki okhorony zdorovia (NROZ) Ukrainy (2017). [Statistical bulletin «National Accounts of Health Care (NAHC) of Ukraine»]. Kyiv: State Statistics Service of Ukraine [in Ukrainian].

2. Sait Derzhavnoi sluzhby statystyky Ukrainy [Sait of State Statistics Service of Ukraine]. http://www.ukrstat.gov.ua/. Retrieved from: http://www.ukrstat.gov.ua/.

3. Sait Instytutu demohrafii ta sotsialnykh doslidzhen imeni M.V. Ptukhy Natsionalnoi akademii nauk Ukrainy [Ptoukha Institute for Demography and Social Studies of the National Academy of Sciences of Ukraine]. https://idss.org.ua. Retrieved from: https://idss.org.ua.

4. Chang, H.-J. (2016). Ekonomika. Instrukciia z vykorystannia [Economy. Instructions for use]. Kyiv: Nash Format [in Ukrainian].

5. Botero, G. (2017). The Reason of State. Chicago: Loyola University [in English].

6. Hamilton, A. (2010). The Works of Alexander Hamilton: [Miscellanies, 1789-1795: France; Duties On Imports; National Bank; Manufactures; Revenue Circulars; Reports On Claims, Etc. Nabu Press [in English]. 
7. Kuznets, S. (1980). Population Capital \& Growth: Selected Essays. W. W. Norton \& Company [in English].

8. Myrdal, G. (1987). Gunnar Myrdal on Population Policy in the Underdeveloped World. Population and Development Review, vol.3, no.13. Population Council. pp. 531-540.

9. List, F. (1909). The National System of Political Economy. London: Longmans, Green and Co [in English].

10. Hirschman, A. (1999). Crossing Boundaries: Selected Writings. NewYork: Zone Books [in English].

11. Lewis, A. (2004). Mashyna ekonomicheskokho rosta zamedliaiet khod [The Slowing Down of the Engine of Growth]. Moscow: Mysl [in Russian].

12. Mochernyi, S.V. (2002). Ekonomichna entsyklopediia: u 3 tomakh [Economic Encyclopedia: in three volumes]. Kyiv: Publishing Center «Academy» [in Ukrainian].

Стаття надійшла до редакиії 04.11.2020 